\title{
SERVING UKRAINIAN CULTURE AND ART
}

\author{
ANATOLII HRYTSAN
}

\begin{abstract}
The article highlights the main achievements of the Educational and Scientific Institute of Arts of Vasyl Stefanyk Precarpathian National University in educational, scientific, artistic and performative spheres.
\end{abstract}

Keywords: Educational and Scientific Institute of Arts, Vasyl Stefanyk Precarpathian National University, Ukrainian culture and art, Prykarpattia.

Fifteen years ago, the Painting and Drawing Department and the Department of Elementary Education and Music of Vasyl Stefanyk Precarpathian University were reorganized into a new division, the Institute of Arts. Today the Institute is a leading academic, research and artistic institution of the region, which is known for its contribution to the musical, theatrical, choreographic, decorative and applied arts of Halychyna, and its studies in the fields of art criticism, culturolgy, professional artistic education.

The first professors of the Painting and Drawing Department and the Department of Elementary Education and Music were M. Figol, Doctor of Art Criticism, Professor, Merited Painter of Ukraine; M. Hrynyshyn, People's Artist of Ukraine, Professor; V. Pashchenko, Merited Artist of Ukraine; M. Mahdii, Merited Artist of Ukraine; V. Zvarun, Merited Artist of Ukraine; L. Yarosevych, Candidate of Art Criticism; V. Yizhak, Merited Culture Worker of Ukraine; Yu. Krykh, Professor, violinist, orchestra conductor.

The Institute owes much to the educators and artists of the above Departments M. Slyvotskyi, Merited Figure of Arts of Ukraine, Professor; I. Fichora, Candidate of Pedagogic Sciences; M. Varennia, Merited Painter of Ukraine; Yu. Lashchuk, Doctor of Art Criticism; B. Stasko, Merited Culture Worker of Ukraine, Professor; O. Nychai, Merited Culture Worker of Ukraine, Professor; S. Dombrovskyi, Associate Professor; R. Dolchuk, Associate Professor; V. Doroniuk, Associate Professor; S. Shumeha, Candidate of Pedagogic Sciences; L. Babii, Candidate of Philosophical Sciences, Professor; I. Batiuzhenko, Associate Professor; V. Luzhnyi, Associate Professor; I. Fitsalovych, member of the National Union of Composers of Ukraine, Professor; P. Terpeliuk, People's Artist of Ukraine, Professor; M. Kanius, member of the National Union of Painters of Ukraine; V. Nesterenko, People's Artist of Ukraine; M. Stankevych, Doctor of Art Criticism, Corresponding Member of the National Academy of Arts of Ukraine.

Now the Institute of Arts has seven professional departments and hires more than 110 professors and accompanists: P. Krul, Doctor of Art Criticism, Professor; H. Karas, Doctor of Art Criticism, Professor; V. Dutchak, Doctor of Art Criticism, Professor; M. Cherepanyn, Merited Artist of Ukraine; 
Kh. Fitsalovych, People's Artist of Ukraine, Professor; M. Kryven, People's Artist of Ukraine, Professor; V. Pirus, People's Artist of Ukraine, Professor; Kh. Mykhailiuk, Merited Figure of Arts of Ukraine, Professor; L. Serhaniuk, Merited Figure of Arts of Ukraine, Professor; B. Hubal, Merited Figure of Arts of Ukraine, Professor; B. Boichuk, Merited Figure of Arts of Ukraine, Professor; V. Savchuk, Associate Professor; M. Ortynska, Merited Artist of Ukraine; M. Popeliuk, Merited Artist of Ukraine; O. Molodii, Merited Artist of Ukraine; M. Bulda, Merited Artist of Ukraine; N. Kukurudza, Merited Culture Worker of Ukraine; Yu. Serhaniuk, Merited Culture Worker of Ukraine; P. Cholovskyi, Merited Culture Worker of Ukraine; N. Hrytsan, Merited Culture Worker of Ukraine; V. Korpaniuk, Merited Master of Folk Arts of Ukraine; V. Sandiuk, Merited Painter of Ukraine; Yu. Voloshchuk, Yu. Yusypchuk, V. Typchuk, L. Khomiak, I. Dundiak, Zh. Zvarychuk, V. Kniaziev, O. Chuiko, I. Yaroshenko, V. Shpilchak, O. Shuliar, I. Taran, L. Pasichniak, O. Fabryka-Protska, T. Osadchuk, Candidates of Art Criticism and Candidates of Pedagogic Sciences; and others.

The Institute of Arts has a significant research and educational potential; it consistently works on the modernization of the educational process and the improvement of practical training of future stage and concert performers, painters, designers, music teachers, choreographers, fine- and applied-art teachers. The primary tasks of the staff are to develop professional competence of their students and to encourage in them independence and creativity.

The Institute educates and trains specialists in different fields of arts and artistic education; it offers doctoral and postgraduate programmes, and refresher courses for those who seek new knowledge and want to develop their pedagogical and artistic skills. Talented young people from the Ivano-Frankivsk, Zakarpattia, Lviv, Ternopil, Rivne, Khmelnytskyi, Kyiv, Poltava Oblasts, from other regions of Ukraine and the Ukrainian diaspora study at the Institute. The Institute of Arts was the first higher educational institution in Prykarpattia to offer education and training in the field of theatrical art. The students' degree project Solodka Darusia (Sweet Darusia, based on the story Solodka Darusia by Maria Matios, supervised by Rostyslav Derzhypilskyi, Director of the Ivano-Frankivsk Oblast Ukrainian Academic Music and Drama Theater named after Ivan Franko) was nominated for the Shevchenko National Prize, the category of Theatrical Arts. The Poetic Theatre's project Povertai do Svoho Zvidtilia (Go to Your That Place, based on Hanna Herman's novel Piramidy Nevydymi (The Invisible Pyramids), directed by Nadiia Hrytsan, Merited Culture Worker of Ukraine) was shown in Kyiv, Rivne, Ivano-Frankivsk and Vinnytsia, and received critical and public acclaim. Now the Theatre is preparing for tours in Europe and America. Their high proficiency and achievements in theatrical art have earned Nadiia Hrytsan and Ihor Prokopiak, Assistant Professors of the Theatrical Art and Choreography Department the Oblast Award in honour of Vitalii Smoliak.

Another aspect of the Institute's work is state-funded researches, the most ambitious projects being The Ensemble Folk-and-Instrumental Tradition of Prykarpattia: The Interaction of Folklore and Academic Trends (conducted by the Department of Ukrainian Musical Studies and Folk and Instrumental Music Art, directed by V. Dutchak, Doctor of Art Criticism, Professor), The Issues of Coordination of Ukrainian and World Experience in Musical and Performing Arts: The Specifics of the National (conducted by the Department of Performing Arts, directed by P. Krul, Doctor of Art Criticism, Professor).

The Institute of Arts has its own scientific publication, Newsletter Precarpathian University. Art studies; the Journal's Scientific Editor is V. Dutchak, Doctor of Art Criticism, Professor. Annually, the professors, $\mathrm{PhD}, \mathrm{MA}$ and $\mathrm{BA}$ students of the Institute publish about 150 monographs, papers, textbooks, guides, educational materials. In the last fifteen years, the Institute has organized more than twenty international, All-Ukrainian and regional scientific/methodological conferences and seminars, contests, festivals highly appraised by Ukrainian and international researchers, educators and viewers.

In 2008, there was created a specialized Dissertation Committee with the function of awarding a candidate's degree in Art Criticism. Its members are renowned Ukrainian specialists in the fields of culturology, decorative and applied arts. The Committee has earned the reputation of an authoritative academic organ.

The Institute of Arts of Vasyl Stefanyk Precarpathian National University is a well-known regional centre of culture and arts; its professors and students plan, organize and actively participate in various 
cultural and artistic projects. The Institute has initiated a convention for students of artistic higher educational institutions, the All-Ukrainian Contests for Young Vocalists named after Ira Malaniuk, a famous Ukrainian and Austrian operatic contralto. Another important project launched by the Institute is the Regional Contest for Young Actors named after Oksana Zatvarska, Merited Artist of Ukraine, first actress of Halychyna to receive this title. The professors and students of the Fine Arts Department and the Decorative and Applied Arts Department had many international (Poland, Romania, Italy, Russia) and national exhibitions; the All-Ukrainian exhibition Nas Sim (There Are Seven of Us) displaying the works by Professors V. Sandiuk, B. Hladkyi, B. Boichuk, B. Hubal, V. Lukan, O. Chuiko, M. Pavliuk, B. Brynskyi was shown in Kyiv, Lviv, Chernivtsi, Ternopil, Uzhhorod, Kamianets-Podilskyi.

The students of the Institute annually win prizes at various contests, festivals and olympiads. In recent years, 43 students of the Institute of Arts have become prize winners and Grand prix winners of All-Ukrainian and international contests and festivals; some of their major achievements are presented below.

At the $3^{\text {rd }}$ Open Contest for Young Actors named after Oksana Zatvarska, 2014-2015, Yurii Vykhovonets, fifth-year student, the class of Associate Professor N. Hrytsan, won the Grand Prix; another student, Oksana Korol got the first-degree award. A team of students won the first-degree award at the International Contest for Young Clothes Designers Vodohrai, the Collection category.

In the last three years, the Institute's best students have received first-degree awards at different contests and festivals; some of the names are presented below:

Viktor Kobets, second-year student, specialty: Decorative and Applied Arts, project director: V. Horodetskyi, Assistant Professor, event: the Ivano-Frankivsk International Blacksmith Festival (Sviato Kovaliv);

Ivan Zbihli, second-year student, specialty: Musical Art, coach: L. Pasichniak, Associate Professor, event: the $3^{\text {rd }}$ All-Ukrainian Contest Festival of Folk Instrument Players Merezhyvo, Rivne;

Gerdan, bandura quartet, leader: V. Dutchak, Doctor of Art Criticism, Professor, event: the $3^{\text {rd }}$ AllUkrainian Contest Festival of Folk Instrument Players Merezhyvo, Rivne;

Viktoriia Kolosova, second-year student, specialty: Music Art, coach: Z. Ros, Assistant Professor, event: the International Festival of Arts Slavic Bazaar, Bulgaria;

Olha Dovhas, third-year student, specialty: Theatrical Art, coach: N. Kukurudza, Associate Professor, event: the All-Ukrainian Contest for Professional Elocutionists named after Ivan Franko, Kyiv;

Andrii Halavai, coach: M. Stefaniuk, Associate Professor, event: the All-Ukrainian Musical Arts Olympiad, Kropyvnytskyi.

The Institute's most famous alumni are Ivan Kuryliuk, People's Artist of Ukraine, Chief Choreographer of Hutsuliia, National Honored Academic Song and Dance Ensemble; Oleksandr Shymanskyi, People's Artist of Ukraine, actor of the Ivano-Frankivsk Oblast Ukrainian Academic Music and Drama Theater named after Ivan Franko; Yaroslava Mosiichuk, People's Artist of Ukraine, actress of the Ternopil Oblast Ukrainian Academic Music and Drama Theater named after Taras Shevchenko; Yaroslav Boruta, People's Artist of Ukraine, Ukrainian composer, poet and songwriter; Halyna Barankevych, Merited Artist of Ukraine; Nadiia Levchenko, Merited Artist of Ukraine; Olesia Pasichniak, Merited Artist of Ukraine; Oleksii Hnatkovskyi, Merited Artist of Ukraine; Olha Komanovska, Merited Artist of Ukraine; Nadiia Komarova, Merited Artist of Ukraine; Mariia Lobur, Merited Artist of Ukraine; Halyna Savchyn, Merited Artist of Ukraine; Nadiia Derkach-Dovzhynska, Merited Artist of Ukraine; Yaroslav Krainyk, Merited Artist of Ukraine; Iryna Lonchyna, Merited Artist of Ukraine; Viktor Hrybyk, Merited Artist of Ukraine. The Institute is proud of its graduates, successful university professors, school teachers, employees of research institutes, heads of educational institutions and children's creativity centres, artistic directors of musical and choreographic groups.

The Institute of Arts extends its international cooperation; it has established professional ties with educational institutions of Italy, Poland, Romania, Greece, Belarus, whose experts and educators are invited to share their experience in innovative artistic forms and technologies, to make presentationi and give master classes for the students and the staff. 
The Institute encourages its students to undertake new forms of artistic and pedagogical activity. Now one of its main educational trends is creating artistic groups that work in different styles and genres. The Institute of Arts maintains close cooperation with the organizations of the National Union of Artists of Ukraine, theatrical and concert institutions, popular folk art groups and ensembles of the Ivano-Frankivsk Oblast.

The Institute of Arts is a unique education and research unit within the structure of Vasyl Stefanyk Precarpathian National University; its major achievement is the development of a coordinated approach to teaching the humanities and arts. Now it is a leading educational, research and methodological centre of Prykarpattia; it is a social and cultural centre known far beyond the region. The tactical task of the Institute is to improve its educational, research and social policy; its strategic tasks are to promote the idea of the national revival and to develop Ukrainian culture.

Address: Anatolii Hrytsan, Vasyl Stefanyk Precarpathian National University, 57, Shevchenko Str., IvanoFrankivsk, 76025, Ukraine.

E-mail: gav@tvnet.if.ua

Received: 14.05.2018; revised: 27.08.2018.

Грицан Анатолій. На службі української культури і мистецтва. Журнал Прикарпатського університету імені Василя Стефаника, 6 (2) (2019), 138-141.

Стаття висвітлює головні здобутки Навчально-наукового інституту мистецтв Прикарпатського національного університету імені Василя Стефаника в освітній, науковій і творчо-виконавській діяльності за роки функціонування.

Ключові слова: Навчально-науковий інститут мистецтв, Прикарпатський національний університет імені Василя Стефаника, українська культура й мистецтво, Прикарпаття. 